DOI: 10.15393/j9.art.2019.5781

УДК 821.161.1.09“16”

А. В. Пигин

Институт русской литературы (Пушкинский Дом), Российская академия наук (Санкт-Петербург, Российская Федерачия) av-pigin@yandex.ru

\title{
Древнерусская Повесть о Христовом крестнике: проблема жанра
}

Аннотация. Повесть о Христовом крестнике - малоизученный памятник русской литературы XVII в., в основе которого лежит международный легендарно-сказочный сюжет о путешествии Божиего крестника на небо, где он становится «заместителем Бога» и вершит суд над грешниками (СУС 800). Текстологический анализ более 30 списков Повести XVII-XIX вв. позволил выделить пять ее редакций. В статье исследуются жанровые особенности этих редакций, устанавливаются связи Повести с агиографией, апокрифической и визионерской литературой, с «душеполезными» повестями из патериков и «Великого Зерцала». Одновременно Повесть может быть истолкована как ранний образец русской «пасхальной повести» (действие происходит на Пасху) и притча. В ней заключен глубокий философский смысл: путь к Богу, Крестному Отцу, возможен только через познание любви к человеку и милосердия как высших ценностей. Для интерпретации Повести привлекается также ее литературное окружение в рукописных сборниках.

Ключевые слова: древнерусская книжность, жанр, пасхальная повесть, притча, сказка, легенда, «бродячие» сюжеты, рукописные сборники

Об авторе: Пигин Александр Валерьевич - доктор филологических наук, профессор, ведущий научный сотрудник, Институт русской литературы (Пушкинский Дом), Российская академия наук (наб. Макарова, 4, г. СанктПетербург, Российская Федерация, 199034)

Дата поступления: 11.01.2019

Дата публикации: 18.10.2019

Для цитирования: Пигин А. В. Древнерусская Повесть о Христовом крестнике: проблема жанра // Проблемы исторической поэтики. - 2019. T. 17. — № 4. - C. 42-67. DOI: 10.15393/j9.art.2019.5781

$\prod$ овесть о Христовом крестнике (или о крестном сыне) конца XVII в., посвященное излюбленным в христианской 
словесности темам Божиего милосердия, покаяния грешника, «земной» и «небесной» справедливости.

Крестным отцом младенца, сына убогих, но благочестивых родителей, оказывается сам Христос. По достижении крестным сыном отроческого возраста Христос приглашает его к себе в гости, на небеса или в чудесный град. Оставшись на некоторое время один, крестник садится на Божий престол и вершит над людьми суд, сурово наказывая грешников. Но Божий суд отличается от человеческого. Бог упрекает своего крестного сына в немилосердии: «Сыне крестный, немилостиво судиши! Посидел ты на моем престоле четверть часа и погубил ты без покаяния народу на земле три тьмы тысяч человек <...>. Аз, Господь, творец всем человеком... не хощу смерти грешника и ожидаю покаяния» [Народные русские легенды: 158]. Господь отправляет крестника на землю, чтобы тот через покаяние и «скорбное житие» заслужил возвращение на небеса, к своему Крестному. Таково содержание легенды, которая легла в основу Повести, но имела и устное бытование (СУС 800).

Повесть была создана, по-видимому, русским книжником, хотя сюжеты о пребывании человека в гостях у Бога и о «судах» на небе являются международными, «бродячими» (ATU 800). Она вполне может быть отнесена к числу тех русских книжных нарративов «переходной эпохи», которые, по характеристике В. В. Сиповского, «не отмечены колоритом времени и места» и представляют собой «разработку ходячих сюжетов» или «претворение чужого сказания в русскую сказку» [Русские повести: XXIX].

Отсутствие российских реалий в Повести, прямой связи ее содержания с исторической действительностью и является, вероятно, главной причиной того, почему Повесть не привлекала к себе внимания исследователей. Сведения о Повести не вошли в обобщающие труды по истории древнерусской литературы, в библиографии по древнерусской повести [Библиография истории], [Библиография древнерусской повести], в справочник И. У. Будовница [Будовниц] и в академический «Словарь книжников и книжности Древней Руси».

В 1859 г. Повесть с некоторыми сокращениями была опубликована А. Н. Афанасьевым в сборнике «Народные русские 
легенды» по рукописи из собрания В. И. Даля [Народные русские легенды: 155-158]. Ученый издал ее в ряду других устных (русского, немецкого, норвежского и валашского) вариантов легенды о пребывании человека в гостях у Бога или Богородицы. В 1720-е гг. дед писателя И. А. Гончарова Иван Иванович Гончаров составил "Летописец семьи Гончаровых", в эту рукопись он включил Страсти Христовы и Повесть о Христовом крестнике. В 1996 г. вся рукопись с "Летописцем...", в том числе Повесть, была опубликована Ю. М. Алексеевой; в комментариях к Повести исследовательница указала на сходство некоторых ее мотивов с древнерусскими апокрифами [Гончаровский летописец: 237-268, 339-347, 370-371]. Повесть упоминается также в работах исследователей творчества Л. Н. Толстого, поскольку она послужила главным источником его рассказа «Крестник» (1886). Сюжет «Христов крестник» отмечен в «Словаре-указателе сюжетов и мотивов русской литературы»; в перечень произведений на этот сюжет включена и Повесть, но без указания списков [Словарь-указатель: 75].

Рукописной традиции Повести была посвящена дипломная работа студентки филологического факультета Санкт-Петербургского (в те годы Ленинградского) государственного университета Г. Г. Малютиной (Бабинцевой), ученицы Н. С. Демковой и М. В. Рождественской (защита в 1974 г.). К сожалению, разыскать эту работу не удалось, но некоторые результаты исследования Г. Г. Малютиной были опубликованы в тезисах ее доклада, прочитанного в Новосибирском государственном университете в 1974 г. [Малютина]. На основе 18 изученных списков Повести исследовательница выделила три варианта ее текста. Наиболее пространный вариант (А) (7 списков) «создан в полном соответствии с житийной традицией, изобилует монологами, длительными и страстными; начинаясь с рассказа о жизни юноши, героя повести, текст завершается описанием смиренного и покаянного конца его» [Малютина: 41]. Вариант AI (10 списков) близок варианту А по изложению сюжета, «но весьма заметно отличается от него стилистически» [Малютина: 40]. Варианты А и АІ Г. Г. Малютина объединяет в одну редакцию, поскольку не видит смысловых 
расхождений между ними. Вариант Б (1 список) является кратким, хотя «ход событий в нем совершенно не нарушен <...>. Он заканчивается описанием “судов” юноши». Особенности текста этого варианта подводят исследовательницу к выводу, что он составляет отдельную редакцию, поскольку книжник вкладывал в легенду «особый, может быть, демократический смысл; действия героя повести представлялись ему единственно справедливыми» [Малютина: 41]. Исследовательница отметила связи Повести с легендами из «Римских деяний», «Звезды Пресветлой», «Великого Зерцала», Пролога, а также с устным народным творчеством. Небольшой объем тезисов не позволил автору аргументировать свои выводы; в публикации не указаны даже шифры изученных рукописей. После защиты дипломного сочинения исследование продолжено не было, и ни одной специальной работы, посвященной Повести, с тех пор не появилось.

Несмотря на «внеисторический» характер Повести, она представляет большой интерес в целом ряде отношений. В Повести затрагиваются важные социально-философские вопросы, которые в дальнейшем приобретут особую актуальность в русской литературе в XIX-XX вв. Можно ли победить царящую в мире несправедливость насилием (а в некоторых списках Повести крестный сын предстает почти как революционер $\left.^{1}\right)$ ? Или же греху должны противостоять милосердие и любовь, а социальное зло преодолевается только путем внутреннего духовного преображения человека? (Не случайно Повесть попала в поле зрения Л. Н. Толстого, создавшего на ее основе собственное произведение.) Изучение рукописной традиции Повести позволяет понять, как книжники XVII-XIX вв. peшали эти этические проблемы, какие аспекты содержания произведения представляли для них наибольший интерес и как расставлялись акценты в ходе его редактирования. При этом редакторские изменения затрагивали и саму литературную основу произведения: в разных вариантах текста обнаруживаются связи Повести то с одним жанром средневековой литературы, то с другим. 
Настоящая статья посвящена проблеме жанрового своеобразия Повести. Однако изучение любого древнерусского сочинения должно начинаться с текстологического анализа его списков. Кратко представлю предварительные результаты исследования рукописной традиции памятника на материале более 30 его списков конца XVII-XIX вв.

Повесть получила распространение как в новообрядческой, так и в старообрядческой среде. Она была известна в различных регионах Севера: в Архангельской, Олонецкой, Вологодской, Псковской губерниях; ее читали в тверской, муромской землях, в Латгалии и т. д. Чаще всего она входила в состав сборников разнообразного литературного содержания, но известны и отдельные рукописи.

Текстологический анализ списков Повести позволил выделить несколько ее редакций (пока воздерживаюсь от определения взаимоотношений между ними).

Первая редакция ${ }^{2}$ (вариант А, по классификации Г. Г. Малютиной) является наиболее объемным текстом: здесь приводится рассказ о благочестивой жизни родителей отрока до его рождения, подробно описано восхождение отрока «в гости» ко Христу по девяти небесам, содержится большой перечень «судов» крестного сына на небе (более 10 в разных списках), в текст включены монологи и диалоги персонажей. Кем на самом деле является его крестный отец, отрок узнает только после возвращения на землю, оказавшись в церкви перед образом Спасителя. Отрок кается в своих согрешениях, пытается вымолить у Бога прощение, ходит «от церькви до церькви по вся дни и нощи», а потом покидает город в поисках спасения. От подаренных отроку его крестным отцом чудесных яблок получают исцеление недужные. Текст заканчивается сообщением о том, что родители отрока приняли постриг и основали обитель во имя Иисуса Христа. Первая редакция представлена двумя вариантами текста, основные отличия которых заключаются в разных перечнях «судов» и в заглавиях: «В льто 6409-е бысть сие преславное чюдо на восточной странъ в единомъ от великихъ градовъ, в немже бысть христианство...» (Ульяновский областной краеведческий музей, 
УКМ 2814, л. 116-131 об., XVIII в.; ИРЛИ, собр. отд. пост. 24, № 79, л. 21-46 об., ХІХ в. и др.); «Слышах убо от палестинских кроник от древних отецъ, добродътельное и иноческое житие проходяще, сицеву повъсть» (ОР РГБ, Музейное собр., № 1835, л. 164-190, XVII в. и др.).

Вторая редакция (вариант AI, по классификации Г. Г. Малютиной) существенно меньше первой редакции по объему, но последовательность событий и общий смысл текста не изменены. Более коротко в этой редакции переданы монологи и диалоги, всего в нескольких предложениях рассказывается о восхождении отрока по небесам, описаны только четыре «суда» (пятый «суд» осуществляется над самим отроком его крестным отцом). В большинстве списков этой редакции местом действия назван некий город Андобург (или Анбур, Антоур и др.) «Венгерской земли», а в заглавии обычно содержится ссылка на Библию (или «Бытие», реже - «Зерцало»): «Выписано из Библии о крестном сыне, како крести Господь младенца». Особенность редакции заключается в усилении мистического, «чудесного» начала: священник удивляется необычному виду восприемника (Христа), во время литургии Христос является к отроку через растворившееся церковное небо; родители не могут поверить рассказу сына о его путешествии к крестному отцу, поскольку он отсутствовал совсем непродолжительное время; ангел Господень запрещает юноше рассказывать об увиденном у Христа и т. д. Несколько иначе во второй редакции повествуется о судьбе юноши после путешествия на небеса: на долгие годы он уходит «в самую далную страну» молиться в пустыни Богу о своем прощении, затем ангел по Божиему велению переносит его домой, где он вскоре умирает, причем за душой отрока является сам Христос и переносит ее в рай; жители Андобурга хоронят тело юноши в церкви св. Димитрия (или Маврикия, Макария, Георгия и др.), где от него происходят чудеса исцеления. Вторая редакция представлена несколькими вариантами, в которых появляются новые мотивы. Так, в некоторых списках перечень «судов» юноши дополняется одним добрым делом: отрок наделяет своих родителей богатством, 
а они в свою очередь раздают его нищим (ОР РГБ, собр. Ундольского, № 663, л. 65-75, XVIII в. и др.).

Первая и вторая редакции обнаруживают отчетливые связи с агиографическими жанрами. Благочестивая жизнь родителей героя, появление младенца на свет по молитвам к Богу после долгих лет бесплодия матери, воспитание отрока «во всякомъ благомъ наказании и хранении», в смирении и отказе «от всякия злыя вещи» - таковы лишь некоторые использованные в Повести агиографические топосы ${ }^{4}$. Традиционным для житий святых является финал второй редакции: от гроба юноши происходят посмертные чудеса. Рассказ первой редакции об основании родителями отрока монашеской обители сближает этот вариант текста с древнерусскими сказаниями о создании монастыря - отдельным жанром древнерусской письменности, формирование которого относится к XV в. (см.: [Охотина-Линд: 27]). Следует заметить, что использование в вымышленном сюжете житийных топосов (вторая редакция является по сути «житием» несуществующего святого) свидетельствует о процессе «обмирщения» агиографии в XVII в.

Обе редакции, особенно первая, испытали, кроме того, сильное влияние апокрифической и визионерской литературы о путешествии по небесам и о видениях или посещениях рая. Так, о путешествии по небесным сферам к Божиему престолу повествуется в апокрифах «Книга Еноха», «Видение пророка Исайи», «Откровение Варуха». Восхищенный на небо апостол Павел («Видение апостола Павла») видит перед собой весь мир: «И возръ(х) от небесъ на землю, и видъ(х) ве(сь) ми(р), и бяше ни во что(ж) пре(д) мною, и видъ(х) сыны человъча, и видъ(х), яко ни во что(ж) ищезающе...» [Мильков: 535] (ср. в Повести: «И егда сядъ на престоль и позрь долу, и открыся ему видъти яко всю землю от моря и до моря и от рЂкъ до конецъ вселенныя. Видя царствы многия и грады великия, и многия, и малыя, и людие ходяще и ползающе, яко малыя зъло мушицы») 5 . Путешественники и визионеры могут получать в раю чудесные дары: старец Агапий принимает от пророка Илии ломоть хлеба («Сказание отца нашего Агапия»), 
некий благочестивый пресвитер приносит из райского сада, как и крестник в Повести, три яблока (Житие Евфросинаповара). В списке второй редакции ОР ГИМ, собр. М. И. Соколова, № 15 (XVIII в.) на небо в гости к Богу отправляется душа юноши, а тело его остается на земле - этот мотив также характерен для жанра средневековых видений и фольклорных «обмираний» (см.: [Пигин]).

Но продолжим характеристику редакций. Две рассмотренные редакции получили в рукописной традиции наиболее широкое распространение, все остальные варианты текста известны пока в одном-двух списках.

Третья редакция - самая краткая (2 списка: ОР БАН, Архангельское собр. С. 138, л. 352 об.-354 об., конец XVII в.; ИРЛИ, собр. отд. пост. 24, № 2, л. 52-57, первая четверть XVIII в. список дефектный, утрачено начало). В списке из Архангельского собрания Повесть имеет заглавие «Бысть сие знамение на восточнъй странъ в Вефулии градъ в льто 6409 году». Это заглавие, перечень «судов» юноши, а также некоторые другие мелкие чтения свидетельствуют о генетической связи третьей редакции с одним из двух вариантов первой редакции (с заглавием «В льто 6409-е бысть сие преславное чюдо...»). Сюжет Повести здесь воспроизводится полно, за исключением финала: в третьей редакции сообщается лишь о возвращении отрока на землю с тремя райскими яблоками, но дальнейшая его судьба не описана. Вероятно, именно этот текст Г. Г. Малютина считала редакцией Б. Более подробно эту редакцию рассмотрим далее.

Четвертая редакция известна пока в одном списке третьей четверти XVIII в. (Вологодский областной краеведческий музей, № 11901, л. 85 об.-98 об.), где имеет следующее заглавие: «Повъсть о нъкоемъ убогом человъцъ, у него же Спаситель восприятъ сына от святыя купъли». Возможно, этот вариант текста сложился в старообрядческой беспоповской среде: обряд крещения младенца совершается здесь не в церкви, а в доме его родителей, причем священник даже не упоминается. Путь юноши в гости к Богу описывается не как восхождение по девяти небесным сферам, но как смена четырех городов - с железными, серебряными, золотыми и хрустальными воротами. Этот мотив 
находит некоторое сходство со сказкой о поисках похищенной матери с посещением героем трех царств - медного, серебряного и золотого (иногда добавляется жемчужное), каждое из которых «лучше» предыдущего [Народные русские сказки: 180-199]. Существенно изменен в этой редакции список «судов» (их 9); с небес юноша приносит не три яблока, как в первой и третьей редакциях, а «некую снедь» и плащаницу, благодаря которой получают исцеление недужные. Заканчивается Повесть сообщением о пострижении юноши в монастыре, в котором он прожил «до старости мастите и скончася о Господе».

Наконец, еще одна редакция представлена двумя списками третьей четверти XIX в., входящими в состав латгальских сборников (ИРЛИ, Латгальское собр., № 228, л. 451 об.-460; № 417, л. 292 об.-300 об.). Сборник Латг.-417 составлен старообрядческим латгальским книжником Л. К. Буцевым, перу которого принадлежат и некоторые другие рукописи в составе Латгальского собрания ИРЛИ (№ 123, 173, 418). Повидимому, эта редакция представляет собой местную - латгальскую - переработку текста XIX в. Повесть имеет здесь заглавие «Выписано из книги Великаго Зьрцала. Слово от Старчества о нбкоемъ человъцъ убоземъ». Ссылки на «Великое Зерцало» и «Старчество» являются ложными, но они могут свидетельствовать об ориентации редактора на определенный тип повествования - краткую «душеполезную» повесть, близкую патериковому рассказу или нравоучительному «прикладу». В этой редакции содержится новый важный мотив: Христос является крестным отцом отрока, но вводится и образ крестной матери - Богородицы. В финале рассказывается о благочестивой жизни отрока и его родителей до самой их смерти, но мотивы строительства монастыря, иноческого пострижения отрока и посмертных чудес от его гроба отсутствуют.

Кроме представленных пяти редакций, встречаются и примеры контаминации вариантов текста, в отдельных списках появляются новые мотивы и подробности.

Итак, редакции и варианты Повести достаточно разнообразны в жанрово-стилистическом отношении: они обнаруживают 
связи с древнерусской агиографией, апокрифами, визионерской литературой, со сказками, с «прикладами» из «Великого Зерцала», с патериковым повествованием. Между тем важно определить и «доминантные» жанровые признаки Повести, являющиеся в той или иной степени общими для всех редакций.

Повесть о Христовом крестнике заманчиво представить, прежде всего, как один из ранних образцов русской пасхальной повести. Жанр пасхального рассказа (или пасхальной повести) в русской литературе впервые получил целостное научное описание в статье В. Н. Захарова [Захаров]. По наблюдениям исследователя, формирование этого жанра относится к 1840-м гг., когда А. С. Хомяков перевел на русский язык «Рождественскую песнь в прозе» Чарльза Диккенса и издал ее под новым заглавием «Светлое Христово Воскресенье» (1844). Это произведение стало открытием нового для русской литературы жанра пасхальной повести [Захаров: 254]. В дальнейшем к этому жанру обращались многие русские писатели: Ф. М. Достоевский («Мужик Марей»), Л. Н. Толстой («После бала»), А. П. Чехов («Студент», «Архиерей»), И. А. Бунин («Легкое дыхание») и другие. Жанр пасхального рассказа должен отвечать двум основным требованиям: «приуроченность времени действия к Пасхальному циклу праздников и “душеспасительное” содержание» [Захаров: 256]. Сюжеты пасхального рассказа - “"духовное проникновение”, “нравственное перерождение человека”, прощение во имя спасения души, воскрешение “мертвых душ”, “восстановление” человека» [Захаров: 256]. Относя раннюю границу жанра к 1840-м гг., В. Н. Захаров имел в виду авторскую художественную литературу, прекрасно осознавая, что истоки пасхальной тематики и пасхальных сюжетов находятся в древнерусской словесности. Одно из самых ранних произведений русской литературы - Слово о Законе и Благодати митрополита Илариона (XI в.) - является по сути и первым ее пасхальным текстом, праздничной пасхальной проповедью.

Все основные события в Повести о Христовом крестнике происходят на Пасху: и первая встреча отрока со своим 
крестным отцом, и путешествие на небо, и «суды», и начало долгого покаянного пути героя. Подробно в Повести представлена сцена христосования мальчика со Христом:

«Слышит звук велик от восточныя страны, оному бо стоящу на западнъй странъ во углЂ едином, отлучившуся. И обозрЂвся, виде нъкоего велможу честна, шествующа к нему со многими восльдствующими дароносцы. И устрашишася зъло отрок той. И егда прииде близ его великий той сановник, и рече ему весело: "Что тако плачеши, чадо, в день всего мира радости? <...> Днесь бо, чадо, не подобает ти плакати без мъры. Вся бо тварь небесная вкупъ и земная ликовствуют Воскресения ради, а ты един плачеши”. <...> Рече же ему великий той могутецъ: “Се, чадо, воистинну аз приях тя от святыя купъли в просвЂщении твоем, и отецъ крестный есть аз. <...>”. И цълова его во уста, и глаголя: “Се, чадо мое крестное, Христос воскресе!” И даруя ему два яйца червленны зъло. Отрок же цъловав его и отвъщав: “Воистинну воскресе Христос и нам даровав живот въчный”. Приим яйца, и поклонися ему до земли трижды, и страхом велиимъ одержим бысть, ничтоже смъя глаголати» ${ }^{6}$.

Пасхальный мотив христосования получает в одной из редакций Повести свое развитие: прихожане и родители отрока удивляются необычности пасхальных яиц, дарованных Христом своему крестнику:

«И въ той церкви предъстояли у того младеньца многие люди, виде у него въ руце держаша два яньць, между собою глаголаху: “Братия, мы таковыхъ янъцъ во всемъ свете не обретаемъ, ни у царя и не у вельможъ великихъ”. И вопроша у младенца: “Чадо, како тебе сии два янъца даша?” Онъ же к нимъ рече: “Сии два янъца даша мне батюшко кресной, которой крестиль меня во имя Отца и Сына и Святаго Духа”. <...> И они чаяхъ ему быти отцу кресному великому вельможе. Младенецъ поиде отъ заутрени въ домъ отца своего и даша имъ по янъцу. Отецъ и мать его смотря на те янъца, зело удивишася, и прославихъ Бога, вопросиша у его: “Чадо, да кто таки два янъца даша? Мы таковы во всемъ свете ни у кого не обретаемъ, ни у царя, ни у вельможъ великихъ”. Онъ же имъ поведа: “Сии два янъца далъ мне батюшко кресной, который крестилъ мя”. <...> И они чаяхъ отцу его кресному великому вельможе» . 
Прихожане, родители да и сам отрок еще не знают, кем в действительности является крестный отец, принимая его за некоего «великого вельможу». Истина открывается только после возвращения отрока на землю, когда он узнает в своем крестном Христа по его изображению на иконе:

«И приидоша ко образу Господа Бога и Спаса нашего Иисуса Христа, велико написанному царскимъ переводом. Юноша же поклонися с родителема своима, востав и зря на образ Господень, и позна, и возопи и великимъ гласом: “О Владыко Господи Боже мой! Воистинну ты еси отецъ мой крестный и восприемник мой бысть от святыя купъли! Воистинъну ты еси! Якоже вижу тя на образе сем написанна, таков есть”. И пад на землю, и паки и возопий гласом велиим: "Помилуй мя, Владыко мой, и прости мя, согрбшившаго к тебъ”. И воставъ, показуя перстомъ на образ Господень трижди: “Воистинну сей есть! Егоже образ сей, той отецъ мой крестный, и у него пребых день сей, согрбших ему без мъры, и отпущенъ бых от него на покаяние. И ктому с вами не могу жити и в дом вашъ возвратитися"» .

С этого момента начинается, по закону пасхальной повести, «"восстановление" человека», «нравственное перерождение» его [Захаров: 256]. Дальнейшая история отрока - это его «второе» путешествие ко Христу. Если «первое» путешествие состоялось в результате чуда, представленного в Повести по законам легендарно-сказочной топики (в сущности отрок не до конца и осознавал, что с ним происходит); то второй раз в «небесную палату» можно войти только пройдя долгий путь внутреннего духовного преображения. Этот нравственный смысл истории отрока прекрасно осознавался книжниками и был предметом их углубленных размышлений. Об этом свидетельствует, прежде всего, разнообразие концовок Повести в редакциях, о чем шла речь выше; кроме того, большой вариативностью отличается и обращенный к отроку заключительный монолог Христа. Редакторы старались подобрать слова, наиболее точно выражающие смысл Божиего напутствия: 


\begin{tabular}{|c|c|c|}
\hline $\begin{array}{c}\text { Первая } \\
\text { редакция }\end{array}$ & қИЯ & Четвертая редакция \\
\hline $\begin{array}{l}\text { «Невозможно } \\
\text { ти, чадо, здь } \\
\text { нын б быти с } \\
\text { нами, но отиди } \\
\text { убо в дом свой } \\
\text { к роди телем } \\
\text { своим. Аще воз- } \\
\text { хощеши, може- } \\
\text { ши мн ог им и } \\
\text { труды и под- } \\
\text { виги внити съмо } \\
\text { многольтным } \\
\text { временем. Нынь } \\
\text { же отиди». }\end{array}$ & $\begin{array}{l}\text { «Сынъ мой кресной! } \\
\text { Немилостивосудишь! } \\
\text { Побылъ ты на моемъ } \\
\text { престоле полминуты } \\
\text { четверти часа, по- } \\
\text { губилъ народу на } \\
\text { земли три тмы ты- } \\
\text { сящы человекъ безъ } \\
\text { покаянии. <...> Чадо } \\
\text { мое и сынъ крестной! } \\
\text { Будеши на земл и, } \\
\text { буди к народу мило- } \\
\text { стивъ. Видя челове- } \\
\text { ка согрешающа, не } \\
\text { осуждай, наипаче } \\
\text { прикрой, въздержи } \\
\text { от блуда и пиянъства. } \\
\text { Азъ тебе уготоваю } \\
\text { полату в седмь сед- } \\
\text { мерицъ». }\end{array}$ & $\begin{array}{l}\text { «Недостоинъ еси с нами здъ } \\
\text { быти, понеже не ожидаеши } \\
\text { грђшниковъ на покаяние, но } \\
\text { сице немилостивъ еси <... } \\
\text { Нынъ же иди, отонуже при- } \\
\text { шелъ еси, и паки внимай } \\
\text { себъ, да не погубиши с нами } \\
\text { пребывания своего, егда паки } \\
\text { призову тя к себъ, и буди } \\
\text { готовъ. <... Иди, мое чадо, } \\
\text { иди, приидеши паки ко мнь, } \\
\text { егда тя призову! Токмо блю- } \\
\text { ди, да не погубиши отечества } \\
\text { своего безвъстно, спаси душу } \\
\text { свою еже по образу нашему, } \\
\text { приимъ кресть свой и посльдуй } \\
\text { ми (Мф. 16, 24), понеже плоть } \\
\text { преходить сия. И прильжи, } \\
\text { чадо мое, о вещи безсмертньй, } \\
\text { да с нами паки здъ возраду- } \\
\text { ется духъ твой (ср.: Лк. 10, 21)»11. }\end{array}$ \\
\hline
\end{tabular}

Повесть представляет собой, таким образом, произведение о пути человека к Богу, что позволяет разглядеть в ней черты жанра притчи. Истинным чудом оказывается не сказочное вознесение к Божиему престолу по небесам или путешествие через волшебные города с диковинными воротами, а обретение Бога через «труды и подвиги», через открытие любви к человеку как высшей ценности.

Притча оказалась очень востребованным жанром в русской литературе XVII в. Кардинальные перемены во всех сферах жизни - государственной, церковной, культурной - располагали писателей этого времени к философскому взгляду на мир и судьбу человека, к обобщениям, подведению итогов, поиску некоего универсального смысла в частном и единичном. Эпизодами-притчами изобилует ранняя старообрядческая 
литература (Житие протопопа Аввакума и др.); горестными размышлениями о «судьбе всего страдающего человечества», о «жизни человека вообще» [Лихачев: 102] исполнена Повесть о Горе-Злочастии; емкий притчевый смысл заключен и в некоторых произведениях «демократической сатиры» (Азбука о голом и небогатом человеке и др.). Притчевые тексты, и в частности повести-притчи XVII в. (Повесть о царе Аггее и др.), как справедливо отмечает Е. К. Ромодановская, способствовали развитию в литературе художественного вымысла, «воспитывали у читателя навык многозначного понимания любого художественного произведения» [Ромодановская, 1985: 50].

С жанром притчи Повесть сближается и по своим стилистическим признакам, и на глубинном содержательном уровне. Важной особенностью притчи является ее абстрагированный характер: отсутствие четких временных и географических координат, анонимность героев, изображение некоего условного «необытовленного» пространства. В некоторых списках время действия в Повести отнесено к 6409 году от Сотворения мира (т. е. к 901 от Рождества Христова): «В льто 6409-е бысть сие преславное чюдо...». Местом действия в списках назван то некий город Андобург Венгерской земли, то библейский Вефул (ср.: Книга Иисуса Навина 19: 4) или Вифлеем, то Магдебург «Цареградской области», то просто некий «от великих солнечных градов» «на восточной стороне». Все персонажи Повести безымянны, лишь в одном из списков отрок получает имя Иоанн ${ }^{12}$. Очевидно, что и дата, и указанные места действия совершенно внеисторичны, являются по сути элементами художественной условности, которую читатель XVII-XVIII вв. уже должен был прекрасно распознавать. Об этом свидетельствует и та легкость, с которой книжники переносили место действия с запада на восток и обратно, хотя, конечно, нельзя исключить того, что кто-то из читателей мог воспринимать содержание и как реально бывшее. Такие же фантастические географические названия характерны и для других древнерусских повестей-притч: город Филумен (Повесть о царе Аггее), Африкия (Повесть об ангеле, ослушавшемся Бога), град Крит (Повесть об Андрее Критском) и др. [Ромодановская, 1994: 41]. Все эти названия выполняют чисто 
орнаментальную функцию, любое из них можно заменить «суть повествования нисколько не пострадает» [Ромодановская, 1994: 41]. Примечательно, что среди географических названий в Повести ни в одном из списков не назван российский город. Российские реалии неизбежно включили бы повествование в исторический контекст и тем самым нарушили бы установку на абстрагирование и универсальность ${ }^{13}$.

Философский (а теперь можно добавить: и притчевый) смысл Повести рождается в столкновении двух этических принципов, о чем уже шла речь выше, - справедливости и милосердия. Тема возмездия за грехи и преступления еще здесь, на земле, а не в потустороннем мире, несомненно, очень волновала читателей Повести, была им по-человечески близка. Не случайно, вероятно, и то, что героем Повести является сын нищих родителей, презираемый всеми окружающими («сосъди не брбгуще о немъ нищеты ради») $)^{4}$, — человек, остро переживающий социальную несправедливость.

Описание «судов» юноши - один из самых вариативных фрагментов в списках: меняются и картины «судов», и их количество, появляются новые важные детали в их осмыслении. Наиболее полные перечни «судов» содержатся в списках первой редакции: по слову отрока на воров падает стена церкви, которую они хотят обокрасть; в морской пучине тонет корабль разбойников, плывущих разграбить монастырь; мечами иссекают друг друга воины нечестивого царя, идущие ратью на христианский город; «камение со огнем» поражают погрязший в преступлениях город и т. д. Некоторые «суды» связаны с нарушением семейной этики, пятой заповеди: некий человек избивает свою мать - у него отсыхают руки, другой бранит своего отца «безстудно» - у него отпадает щека; невестка хочет отравить зельем свою свекровь, но погибает сама. Другие «суды» имеют сугубо социальный смысл: юноша наказывает богача, лишающего бедняка его последнего имущества, и судью, который решает судебное дело не по закону, а за мзду, или приговаривает невиновного к смертной казни. Наказаны и скупцы, и прелюбодеи, и сквернословы, и клеветники, и даже колдуны («чаровники»), наносящие порчу плодородию земли и домашнему скоту. 
Многочисленные детали и уточнения к описанию «судов» в разных списках показывают, что книжники то осуждали юношу, то находили некоторое оправдание для него. Так, в отдельных списках сообщается, что во время «судов» погибали, кроме грешников, ни в чем не повинные люди. В других вариантах текста отрок призывает на нечестивых Божий гнев или перед каждым «судом» взывает к Богу о помощи («Даждь, Господи...»), что в какой-то мере смягчает его вину, поскольку наказания совершаются пусть и по его прошениям, но по воле Бога. Еще в одном варианте возмездие осуществляется руками самих гонимых: отрок видит, как некая женщина избивает несчастную вдову - по его повелению вдова убивает свою обидчицу и уходит прочь; в другой сцене оклеветанный неким вельможей в краже денег человек убивает и его самого, и судью, вынесшего неправедный приговор за несовершенное преступление; после этого убийства человек отправляется в дом к вельможе и завладевает всем его имуществом. Отрок, таким образом, не только берет грех на свою душу, но и заставляет совершить преступления тех, кого хотел спасти. Конечно, в каждом подобном случае редактирования трудно сказать наверняка, какой именно смысл вкладывал книжник: сочувствовал ли он герою Повести, разделяя вместе с ним, хотя бы на мгновение, желание покарать таким образом зло, или осуждал его. Не будет, наверное, парадоксом заявить, что психологически вполне допустимо и совмещение этих чувств и оценок ${ }^{15}$. Впрочем, в тех случаях, когда в списках Повести даются прямые авторские комментарии к действиям отрока, всегда звучит осуждение: «И съдя на престоль, судя без милости, забыв себе, яко ничтоже есть, но токмо земля и пепелъ» ${ }^{16}$.

К жанру притчи (или повести-притчи) особенно близка третья редакция Повести. Она, напомню, самая краткая, здесь воспроизводится лишь событийная канва произведения, что характерно для притчи, избегающей лишних подробностей и развернутых диалогов. Как уже было сказано, по-видимому, именно этот текст Г. Г. Малютина относила к редакции Б. Особенности этой редакции - пространный перечень «судов» и отсутствие рассказа о покаянии юноши - позволили Г. Г. Малютиной увидеть в повествовании «демократический смысл»: 
действия героя Повести, по ее мнению, представлялись автору «единственно справедливыми» [Малютина: 41]. Между тем для такого вывода нет никаких оснований. Дилемма человеческого и Божиего суда здесь по-прежнему решается в пользу Христа, в словах которого и заключается единственно возможное понимание рассказанной истории: «Почто ты многихъ погубилъ еси безвременно и без покаяния? А мнози бы покаялися, аще бы милосердие к нимъ явилъ» ${ }^{17}$. Заключительная сцена Повести в этой редакции - исцеление недужных от дарованных Христом яблок - подтверждает правоту Бога на символическом уровне. Рассказ о дальнейшей истории юноши редактор считал, вероятно, избыточным, поскольку на главный вопрос - на чьей стороне правда - ответ уже был дан.

Для понимания того, как осмыслялся текст Повести в этой редакции, большой интерес представляет ее «литературный конвой» в сборнике ОР БАН, Архангельское собр. С. 138. Этот объемный сборник конца XVII в. (форматом «в лист», 428 л.) принадлежал библиотеке архиепископа Афанасия Холмогорского. Составители описания сборника отмечают, что «рукопись предполагалось сформировать как собрание расположенных по алфавиту выписок из памятников нравоучительных, церковных, церковноисторических, исторических и литературных» [Описание рукописного отдела: 249]. Раздел каждой буквы начинается с выписок из «Деяний» Цезаря Барония, далее из Хронографа, из Скитского патерика, из «Великого Зерцала» и Пролога. Но алфавитный порядок часто нарушается, иногда под той или иной буквой содержатся тексты, не относящиеся к ней (по первому слову, по именам и т. д.), включаются выписки из других памятников или целые литературные и исторические произведения [Описание рукописного отдела: 249-252]. Несмотря на эти композиционные нарушения и разнообразие включенных в рукопись памятников, подбор текстов был явно продуман и подчинен определенной логике, что заставляет внимательно присмотреться, в каком окружении оказался интересующий нас текст.

Повесть (в списке третьей редакции) включена в сборник в раздел под буквой «Ч», в состав которого входит также 
историческая повесть о московском митрополите Филиппе (Колычеве). Исследовательница данной повести И. А. Лобакова справедливо отмечает, что «подборка текстов в этой главе диктовалась в основном двумя главными идеями: "пременение царств” из-за прегрешений народа и властителей; проблема соотношения справедливости и милосердия» [Лобакова: 302]. Повесть о Христовом крестнике и следующая за ней в рукописи повесть о митрополите Филиппе оказываются по своей проблематике близки, поскольку в последней «жестокий несправедливый самодержец (Иван Грозный. А. П.), “разделивший царство”, противопоставлен милосердному святителю (митрополиту Филиппу. - А. П.)» [Лобакова: 302-303]. Святитель обличает Ивана Грозного в том, что царь творит «суд не по правде», «неповинно кровь лиется христианская, и напрасно умирают»; царский сан высок, но «царственная честь преходитъ и смертию поглощается» [Лобакова: 310-311].

Тема царя и «пременения царств» лежит в основе и некоторых других произведений в разделах на букву «Ч» и соседних «Ц», «Ч», Ш»: в многочисленных выписках из Хронографа и других сочинений о добрых и порочных государях, в том числе российских, в статье «Аристотель премънение царства быти глаголетъ...», в повествовании о падении царства Дария и о взятии Константинополя турками, в переводе сочинения А. Гваньини об Иване Грозном и об опричнине, в сочинении о Смутном времени «Повесть о видении некоему мужу духовну» (1606), в которой содержится грозное пророчество о Божией каре на Российское государство, ибо «нъсть истинны во царъх, и патриархахъ, и во всемъ церковномъ чину...» ${ }^{18}$, и др.

Произведения на эту тему составляют в рукописи важный контекст для Повести, актуализирующий весьма значимые аспекты ее содержания, которые, может быть, без «литературного конвоя» были бы не столь очевидны. В облике Христа в произведении нарочито подчеркиваются его царские атрибуты: «И ту узрь отца своего крестнаго, сьдяща на престоль высоцъ иарстю, на главъ его бяше вьнецъ, и прочая на немъ одъяния царския, и жезлъ в руку его изарскици»? ${ }^{19}$. В первой редакции, с которой третья связана генетически, сообщается, 
что и сама икона Спасителя, благодаря которой отрок узнал наконец, кем является его крестный отец, была написана «царскимъ переводом» (или «царскимъ подобиемъ»). Присвоение отроком полномочий «высшей власти» на время отсутствия Христа - Царя Небесного («Царь же Небесный отиде...») - может быть истолковано как акт самозванства, герой становится лжецарем: «Юноша же единъ остася, видъв порфиру иарскую и вънецъ, и престоль ияарскиц̆, и приступи дерзостно, и вземъ в руку, и смотряше. О, дивенъ еси, Господи! Аки бы в забытие прииде юноша той! И нача вся ияарская одъяние воздъ и жезлъ вземъ в руку своею, и на престоль и,арский всълъ» ${ }^{20}$. Нетрудно догадаться, какие исторические ассоциации в недавнем прошлом России должны были вызывать у читателя эти сцены. Возможно, именно по этой причине рассказ о покаянии юноши в третьей редакции был полностью снят - исторический деятель, с которым мог ассоциироваться крестник, остался в национальной памяти как богоотступник. В тексте этой редакции (как и во всех других) никаких прямых аллюзий к истории Лжедмитрия, конечно, нет, как нет и каких-либо других российских реалий. Но в этом и заключается специфика притчевых текстов, параболы: в конкретной истории притчи, в ее фабуле открывается универсальный, предельно абстрагированный смысл, но возможен и обратный путь, когда в абстракции вдруг начинает угадываться злободневное содержание. Третья редакция (в списке ОР БАН, Архангельское собр. С. 138, с учетом «литературного конвоя») действительно стоит, таким образом, несколько особняком среди текстов Повести. Но не потому, что редактор считал действия отрока справедливыми, а потому, что пасхальная тема “восстановления” человека» уступает здесь место историософской проблематике, размышлениям о нравственной основе высшей государственной власти ${ }^{21}$.

В понимании жанровой специфики Повести важен еще один аспект: при всем жанрово-стилистическом разнообразии ее вариантов мы не встречаем комического осмысления сюжета, новеллистических версий. Между тем в западноевропейской традиции, в частности в немецких сборниках фацеций Генриха Бебеля и сказок братьев Гримм, сюжет ATU 800 
имеет откровенно комический характер ${ }^{22}$. Вопрос о происхождении Повести остается пока открытым, но использование при ее создании какой-то устной или литературной европейской версии сюжета ATU 800 представляется более чем вероятным. Если это предположение верно, то сюжет ATU 800 разделил на русской почве судьбу многих других заимствованных из Европы в XVII в. «смехотворных» текстов, которые «видоизменялись в рукописных пересказах некоторыми бытовыми подробностями и нередко утрачивали веселый колорит своих первичных оригиналов» [Веселовский: 497]. Европейская фацеция, шутливая сказка превратилась на русской почве в философскую (историософскую) повесть-притчу.

И последнее. В изучении Повести, в том числе жанровых особенностей отдельных разновидностей ее текста, необходимо привлечение фольклорных вариантов сюжета. Вариативность текста Повести может объясняться среди прочего постоянным взаимовлиянием книжных и фольклорных версий легенды. Но это предмет специального исследования, которому должен предшествовать сравнительный анализ фольклорных сюжетов о крестнике Бога ${ }^{23}$ и о "судах» на небе в восточнославянской и западноевропейской традициях.

\section{Список сокращений}

ИРЛИ - Институт русской литературы (Пушкинский Дом) РАН (С.-Петербург).

ОР БАН - Отдел рукописей Библиотеки Российской академии наук (С.-Петербург).

ОР ГИМ - Отдел рукописей Государственного исторического музея (Москва).

ОР РГБ - Отдел рукописей Российской государственной библиотеки (Москва).

СУС - Сравнительный указатель сюжетов. Восточнославянская сказка / сост. Л. Г. Бараг, И. П. Березовский, К. П. Кабашников, Н. В. Новиков. Л.: «Наука», 1979.

ТОДРЛ - Труды Отдела древнерусской литературы.

ATU - Uther H.-J. The Types of International Folktales. A Classification and Bibliography. Helsinki, 2004. Parts 1-3. 


\section{Примечания}

1 Ср. один из «судов» отрока: «И паки видитъ нъкоего силнаго человъка, лишающа мзды его и оного бъдного плачюща горко. Онъ же (крестный сын. - А. П.) рече: “Да падъ умретъ сильный, а богатство его да дастся тому, его же онъ обидъ”. И бысть тако» (Вологодский краеведческий музей, № 11901, л. 94 об., XVIII в.).

2 Порядковые номера присвоены редакциям только для удобства их рассмотрения; реальную картину соотношения и последовательности возникновения редакций они не отражают.

3 ИРЛИ, собр. отд. пост. 24, № 79, л. 45 об., ХІХ в.

4 Проблеме агиографической топики на древнерусском материале посвящены работы Т. Р. Руди: [Руди, 2005, 2006].

5 ИРЛИ, собр. отд. пост. 24, № 79, л. 38 об.

6 ОР РГБ, Музейное собр., № 1835, л. 141 об.-142 (первая редакция).

7 ОР БАН, 33.14.10, л. 46 об.-47 об. (вторая редакция).

8 ОР РГБ, Музейное собр., № 1835, л. 155-155 об.

9 Там же. Л. 153 об.-154.

10 ОР БАН, 33.14.10, л. 53.

11 Вологодский областной краеведческий музей, № 11901, л. 95-96.

12 ОР ГИМ, собр. М. И. Соколова, № 15, л. 202 об.-214, XVIII в.

13 Ср. с наблюдением Е. К. Ромодановской: вымысел в древнерусской беллетристике «стоит как бы вне русской жизни» [Ромодановская, 1994: 33]. ИРЛИ, собр. отд. пост. 24, № 79, л. 26 об.-27.

15 Вероятно, уместно в этой связи напомнить знаменитую сцену из «Братьев Карамазовых» Ф. М. Достоевского. Рассказав Алеше Карамазову историю о том, как по приказу генерала был растерзан псами мальчик на глазах у матери, Иван Карамазов задает брату вопрос: «Ну... что же его (генерала. - А. П.)? Расстрелять? Для удовлетворения нравственного чувства расстрелять? <...>

- Расстрелять! - тихо проговорил Алеша, с бледною, перекосившеюся какою-то улыбкой подняв взор на брата.

- Браво! - завопил Иван в каком-то восторге, - уж коли ты сказал, значит... Ай да схимник! Так вот какой у тебя бесенок в сердечке сидит, Алешка Карамазов!

- Я сказал нелепость, но...

- То-то и есть, что но... - кричал Иван. - Знай, послушник, что нелепости слишком нужны на земле. На нелепостях мир стоит...» [Достоевский: 221].

16 ИРЛИ, собр. отд. пост. 24, № 79, л. 42-42 об.

17 ОР БАН, Архангельское собр. С. 138, л. 354 об.

18 Там же. Л. 327.

19 Там же. Л. 354.

20 Там же.

21 Другой, более поздний, список третьей редакции - ИРЛИ, собр. отд. пост. 24, № 2, л. 52-57 - входит в состав сборника-конволюта, состоящего 
из пяти рукописей конца XVII - начала XIX в. С Повести начинается вторая рукопись этого сборника (первая четверть XVIII в.), включающая в основном краткие повести из «Великого Зерцала» и патериков. Произведения на «царскую тему» в этой подборке отсутствуют, а вслед за Повестью переписана повесть о чуде на Пасху об оживленной курице с толкованием символики пасхального яйца. Таким образом, Повесть о Христовом крестнике, по-видимому, воспринималась составителем рукописи, прежде всего, как рассказ о пасхальном чуде.

22 ATU 800: The Tailor in Heaven (Портной на небесах). Хромой портной, промышлявший воровством обрезков ткани, упрашивает апостола Петра пустить его в рай; оставшись один, он самовольно садится на Божий престол, наблюдает за человеческими делами, бросает скамеечку Бога в старуху, которая полоскала в ручье белье и украла два покрывала. Господь возвращается и изгоняет его из рая со словами: «О ты, лукавец! Да ведь если бы я вздумал так судить, как ты судишь, что бы с тобою-то должен был сделать? <...> Ведь тогда бы у меня здесь ни стульев, ни скамей, ни кресел, ни даже кочерги не осталось - все бы пришлось побросать на вас, грешников!» [Гримм Я., Гримм В.: 178-179]. В качестве близкой параллели к Повести о Христовом крестнике эту сказку (из сборника братьев Гримм) приводил еще А. Н. Афанасьев в «Народных русских легендах» (ср. также: [Бебель: 16-17]).

23 Сказкам о «чудесном крестном» посвящены работы Е. И. Лутовиновой, однако сюжет СУС 800 исследовательница не рассматривает, ограничивая свой материал сказками, относящимися к СУС 332, 471 и 710 [Лутовинова, 2009a], [Лутовинова, 2009b: 104-113].

\section{Список литературы}

1. Бебель Г. Фацетии / изд. подгот. Ю. М. Каган. - М.: Наука, 1970. - 328 с.

2. Библиография древнерусской повести / сост. А. А. Назаревский. М.; Л.: Изд-во АН СССР, 1955. - 192 с.

3. Библиография истории древнерусской литературы. - М.; Л.: Изд-во Академии наук СССР, 1940. Вып. 1: Древнерусская повесть / сост. В. П. Адрианова-Перетц и В. Ф. Покровская. - 326 с.

4. Будовниц И. У. Словарь русской, украинской, белорусской письменности и литературы до XVIII века. - М.: Изд-во АН СССР, 1962. - 400 с.

5. Веселовский А. Н. Памятники литературы повествовательной // Галахов А. История русской словесности, древней и новой. - 2-е изд. СПб., 1880. - Т. 1. - С. 394-517.

6. Гончаровский летописец / подгот. текста и примеч. Ю. М. Алексеевой. Ульяновск: Дом печати, 1996. - Вып. 1: Летописец семьи Гончаровых. -382 c.

7. Гримм Я., Гримм В. Сказки братьев Гримм: Полн. собр.: в 2 т. - М.: Лексика, 1997. - Т. 1. - 478 с. 
8. Достоевский Ф. М. Полн. собр. соч.: в 30 т. — Л.: Наука, 1976. - Т. 14: Братья Карамазовы. - Книги I-X. - 511 с.

9. Захаров В. Н. Пасхальный рассказ как жанр русской литературы // Проблемы исторической поэтики. - Петрозаводск: Изд-во ПетрГУ, 1994. - Вып. 3. - С. 249-261 [Электронный ресурc]. - URL: http:// poetica.pro/journal/article.php?id=2403 (20.12.2018). DOI: 10.15393/ j9.art.1994.2403

10. Лихачев Д. С. Жизнь человека в представлении неизвестного автора XVII века // Повесть о Горе-Злочастии / изд. подгот. Д. С. Лихачев, Е. И. Ванеева. - Л.: Наука, 1985. - С. 89-105.

11. Лобакова И. А. Историческая повесть о митрополите Филиппе. Литературные источники и их интерпретация конца XVII в. // ТОДРЛ. СПб.: Дмитрий Буланин, 2004. - Т. 55. - С. 301-312.

12. Лутовинова Е. И. Русские волшебные сказки о чудесном крестном // Искусство и образование. Журнал методики, теории и практики художественного образования и эстетического воспитания. $-2009 .-$ № 3 (59). - С. 116-121. (a)

13. Лутовинова Е. И. Сюжетология волшебной сказки. - М.: Искусство и образование, 2009. -190 c. (b)

14. Малютина Г. Г. Из истории русской повести XVII в. «Повесть о крестном сыне» // Материалы XII Всесоюзной научной студенческой конференции. Апрель 1974. Филология. - Новосибирск, 1974. - С. 40-42.

15. Мильков В. В. Древнерусские апокрифы. - СПб.: РХГИ, 1999. - 894 с.

16. Народные русские легенды А. Н. Афанасьева / предисл., состав. и коммент. В. С. Кузнецовой. - Новосибирск: Наука, 1990. - 270 с.

17. Народные русские сказки А. Н. Афанасьева: в 3 т. / изд. подгот. Л. Г. Бараг и Н. В. Новиков. - М.: Наука, 1985. - Т. 1. - 512 с.

18. Описание рукописного отдела Библиотеки Академии наук СССР - М.; Л.: Наука, 1965. - Т. 3. - Вып. 2: Исторические сборники XV-XVII вв. / сост. А. И. Копанев, М. В. Кукушкина, В. Ф. Покровская. -362 с.

19. Охотина-Линд Н. А. Сказание о Валаамском монастыре. - СПб.: Глаголъ, 1996. - 256 с.

20. Пигин А. В. Видения потустороннего мира в русской рукописной книжности. - СПб.: Дмитрий Буланин, 2006. - 432 с.

21. Ромодановская Е. К. Повести о гордом царе в рукописной традиции XVII-XIX веков. - Новосибирск: Наука, 1985. - 384 с.

22. Ромодановская Е. К. Русская литература на пороге нового времени: Пути формирования русской беллетристики переходного периода. Новосибирск: Наука, 1994. - 232 с.

23. Руди Т. Р. Топика русских житий (вопросы типологии) // Русская агиография. Исследования, публикации, полемика / отв. ред. С. А. Семячко. - СПб.: Дмитрий Буланин, 2005. - С. 59-101.

24. Руди Т. Р. О композиции и топике житий преподобных // ТОДРЛ. СПб.: Дмитрий Буланин, 2006. - Т. 57. - С. 431-500. 
25. Русские повести XVII-XVIII вв. / под ред. и с предисл. В. В. Сиповского. - СПб.: Изд. А. С. Суворина, 1905. - 308 с.

26. Словарь-указатель сюжетов и мотивов русской литературы: экспериментальное издание / отв. ред. Е. К. Ромодановская. - Новосибирск: Изд-во СО РАН, 2006. - Вып. 1. - 243 с.

\title{
Alexander V. Pigin
}

The Institute of Russian Literature (Pushkinsky Dom),

The Russian Academy of Sciences

(Saint Petersburg, Russian Federation)

av-pigin@yandex.ru

\section{The Old Russian Tale of Christ's Godson: the Problem of Genre}

\begin{abstract}
The Tale of Christ's Godson is a literary landmark of the 17th century, studied insufficiently. It is based on a legendary international fairytale plot about a trip of God's godson to the heavens, where he becomes a "deputy God" and holds court over sinners (Comparative Index of Plots. Eastern-Slavic Fairy Tale, 800). A textological analysis of over 30 manuscript copies of the Tale of the 17th-19th centuries allowed us to identify its five editions. The article studies genre features of these editions, discovers ties of the Tale with hagiographic, apocryphic and visionary literature as well as with edificatory tales from patericons and "Great Mirror". At the same time, the Tale can be seen as an early sample of the Russian "Easter tale" (the event takes place at Easter) and a parable. It contains a deep philosophical sense: a way to God, to the Godfather, is only possible through the knowledge of love and mercy toward Man as the supreme values. In order to interpret the Tale, the author of the article draws other texts from manuscript codices.
\end{abstract}

Keywords: the Old Russian literature, genre, Easter tale, parable, fairy tale, legend, wandering plots, manuscript codices

About the author: Pigin Alexander V. - Doctor of Philology, Professor, Leading Researcher, The Institute of Russian Literature (Pushkinsky Dom), T he Russian Academy of Sciences (nab. Makarova 4, Saint Petersburg, 199034, Russian Federation)

Received: January 11, 2019

Date of publication: October 18, 2019

For citation: Pigin A. V. The Old Russian Tale of Christ's Godson: the Problem of Genre. In: Problemy istoricheskoy poetiki [The Problems of Historical Poetics], 2019, vol. 17, no. 4, pp. 42-67. DOI: 10.15393/j9.art.2019.5781 (In Russ.) 


\section{References}

1. Bebel' G. Fatsetii [Facetiae]. Moscow, Nauka Publ., 1970. 328 p. (In Russ.)

2. Bibliografiya drevnerusskoy povesti [The Bibliography of the Old Russian Tale]. Moscow, Leningrad, Academy of sciences of the USSR Publ., 1955. 192 p. (In Russ.)

3. Bibliografiya istorii drevnerusskoy literatury [The Bibliography of the History of Old Russian Literature]. Moscow, Leningrad, Academy of sciences of the USSR Publ., 1940, issue 1. 326 p. (In Russ.)

4. Budovnits I. U. Slovar' russkoy, ukrainskoy, belorusskoy pis'mennosti i literatury do XVIII veka [The Dictionary of Russian, Ukrainian and Belorussian Writings and Literature Until the 18th Century]. Moscow, Academy of sciences of the USSR Publ., 1962. 400 p. (In Russ.)

5. Veselovskiy A. N. Monuments of the Narrative Literature. In: Galakhov A. Istoriya russkoy slovesnosti, drevney $i$ novoy [Galakhov A. The History of Russian Ancient and New Literature]. St. Petersburg, 1880, vol. 1, pp. 394-517. (In Russ.)

6. Goncharovskiy letopisets [Goncharov's Chronicler]. Ulyanovsk, Dom pechati Publ., 1996, issue 1: The Chronicler of the Goncharov's Family. 382 p. (In Russ.)

7. Grimm J., Grimm W. Skazki brat'ev Grimm: Polnoe sobranie: $v 2$ tomakh [Fairy Tales of the Brothers Grimm: The Complete Collection: in 2 Vols]. Moscow, Leksika Publ., 1997, vol. 1. 478 p. (In Russ.)

8. Dostoevskiy F. M. Polnoe sobranie sochineniy: $v 30$ tomakh [The Complete Works: in 30 Vols]. Leningrad, Nauka Publ., 1976, vol. 14: The Brothers Karamazov, books 1-10.511 p. (In Russ.)

9. Zakharov V. N. Easter Story as a Russian Literary Genre. In: Problemy istoricheskoy poetiki [The Problems of Historical Poetics]. Petrozavodsk, Petrozavodsk State University Publ., 1994, issue 3, pp. 249-261. Available at: http://poetica.pro/journal/article.php?id=2403 (accessed on December 20, 2018). DOI: 10.15393/j9.art.1994.2403. (In Russ.)

10. Likhachev D. S. Human Life in the View of an Unknown Author of the 17th Century. In: Povest'o Gore-Zlochastii [The Tale of Woe and Misfortune]. Leningrad, Nauka Publ., 1985, pp. 89-105. (In Russ.)

11. Lobakova I. A. The Historical Tale About Metropolitan Philip. Literary Sources and Their Interpretation of the Late 17th Century. In: Trudy Otdela drevnerusskoy literatury [Proceedings of the Department of Old-Russian Literature of the Pushkin House of the USSR Academy of Sciences]. St. Petersburg, Dmitriy Bulanin Publ., 2004, vol. 55, pp. 301-312. (In Russ.)

12.Lutovinova E. I. Russian Fairy Tales About a Miraculous Godfather. In: Iskusstvo i obrazovanie. Zhurnal metodiki, teorii i praktiki khudozhestvennogo obrazovaniya $i$ esteticheskogo vospitaniya [Art and Education. Journal of Methodology, Theory and Practice of Artistic and Aesthetic Education], 2009, no. 3 (59), pp. 116-121 (In Russ.) (a)

13. Lutovinova E. I. Syuzhetologiya volshebnoy skazki [The Plot of Fairy Tales]. Moscow, Iskusstvo i obrazovanie Publ., 2009. 190 p. (In Russ.) (b) 
14. Malyutina G. G. From the History of the Russian Tale of the 17th Century. "The Tale of Godson". In: Materialy XII Vsesoyuznoy nauchnoy studencheskoy konferentsii. Aprel 1974. Filologiya [Proceedings of the 12th All-Union Scientific Student Conference. April 1974. Philology]. Novosibirsk, 1974, pp. 40-42. (In Russ.)

15. Mil'kov V. V. Drevnerusskie apokrify [The Old Russian Apocrypha]. St. Petersburg, The Russian Christian Institute for the Humanities Publ., 1999. 894 p. (In Russ.)

16. Narodnye russkie legendy A. N. Afanas'eva [Folk Russian Legends by A. N. Afanasyev]. Novosibirsk, Nauka Publ., 1990. 270 p. (In Russ.)

17. Narodnye russkie skazki A. N. Afanas'eva: $v 3$ tomakh [Folk Russian Fairy Tales by A. N. Afanasyev: in 3 Vols]. Moscow, Nauka Publ., 1985, vol. 1. 512 p. (In Russ.)

18. Opisanie rukopisnogo otdela Biblioteki Akademii nauk SSSR [The Description of the Manuscript Department of the Library of the Academy of Sciences of the USSR]. Moscow, Leningrad, Nauka Publ., 1965, vol. 3, issue 2: Historical Collections of the 15th-17th Centuries. 362 p. (In Russ.)

19. Okhotina-Lind N. A. Skazanie o Valaamskom monastyre [The Tale of the Valaam Monastery]. St. Petersburg, Glagol Publ., 1996. 256 p. (In Russ.)

20.Pigin A. V. Videniya potustoronnego mira v russkoy rukopisnoy knizhnosti [The Visions of the Otherworld in Russian Manuscript Literature]. St. Petersburg, Dmitriy Bulanin Publ., 2006. 432 p. (In Russ.)

21. Romodanovskaya E. K. Povesti o gordom tsare v rukopisnoy traditsii XVIIXIX vekov [Tales About a Proud King in the Manuscript Tradition of the 17th-19th Centuries]. Novosibirsk, Nauka Publ., 1985. 384 p. (In Russ.)

22. Romodanovskaya E. K. Russkaya literatura na poroge novogo vremeni: Puti formirovaniya russkoy belletristiki perekhodnogo perioda [Russian Literature on the Verge of Modern Times: Ways of Formation of the Russian Belles-Lettres in the Transitional Period]. Novosibirsk, Nauka Publ., 1994. 232 p. (In Russ.)

23. Rudi T. R. The Topic of the Lives of Saints (Issues of Typology). In: Russkaya agiografiya. Issledovaniya, publikatsii, polemika [The Russian Hagiography. Research, Publications, Dispute]. St. Petersburg, Dmitriy Bulanin Publ., 2005, pp. 59-101. (In Russ.)

24. Rudi T. R. On the Composition and the Topic of the Lives of Monks. In: Trudy Otdela drevnerusskoy literatury [Proceedings of the Department of Old-Russian Literature of the Pushkin House of the USSR Academy of Sciences]. St. Petersburg, Dmitriy Bulanin Publ., 2006, vol. 57, pp. 431-500 (In Russ.)

25. Russkie povesti XVII-XVIII vv. [Russian Tales of the 17th-18th Centuries]. St. Petersburg, Izdanie A. S. Suvorina Publ., 1905. 308 p. (In Russ.)

26. Slovar'-ukazatel' syuzhetov i motivov russkoy literatury: eksperimental'noe izdanie [The Dictionary-Index of Plots and Motifs of Russian Literature: Experimental Edition]. Novosibirsk, The Siberian branch of the Russian Academy of Sciences Publ., issue 1. 243 p. (In Russ.) 